\title{
RARE-ELEMENT (Li-RICH) GRANITIC AND PEGMATITIC PLUTONS: A PRIMARY OR SUPERIMPOSED SIGNATURE?
}

\section{BERNARD CHAROY AND FERNANDO NORONHA}

\begin{abstract}
Bulk mineral compositions, phase relationships and primary versus metasomatic status of mineral assemblages in Li-rich pegmatites (or equivalents) are generally complex. In recent years, a considerable amount of interest has been paid to rare-met al granite-like entities characterized by an extreme enrichment in rare met als, together with volatiles as fluxing agents. A central question about the meaning of such evolved systems (intrusive, eruptive or pegmatitic equivalents) is whether their distinctive chemical signature is (1) magmatic or (2) due to subsolidus modification through addition from a superimposed or derivative fluid phase or a mixture of both. Another question is the proportions of the subsolidus fluids and whether it is a specific character or a convergence phenomenon. The study on evolved granitic and pegmatitic plutons from the Hercynian belt of France and Portugal indicate that some plutons reached their specialized status at the magmatic stage, and Li is hosted by the major primary phases. In other plutons, however, rare elements are of secondary, metasomatic origin. All studied plutons are volumetrically small, implying in small batches of magma, due to either a small melting fraction of crustal source of restricted composition, or a late withdraw of a residual liquid. The real significance of the high concentrations of the rare elements Li-rich pegmatites is undefined, because spatial and genetic relationships with larger magmatic plutons are often lacking.
\end{abstract}

Keywords : rare met al, granites, lithium, magmatism, metasomatism

GEOLOGY The Hercynian (Variscan) orogeny has a main role on the geologic evolution of western Europe. The Hercynian belt is characterized by several, roughly EW trending, geotectonic zones with specific and peculiar paleogeographic, tectonic, metamorphic and magmatic characteristics. These zones define structural lineaments in the chain forming the Ibero-Armorican virgation (Matte \& Ribeiro 1975, Dias \& Ribeiro 1995) (Fig. 1). Tectonic characteristics of the European Variscides are those of a classical obduction-collision belt The arcuate belt originated with the convergence, obduction, subduction and collision of the North Laurentia and the Gondwana continents, with minor intermediate blocks. It is described as a stacking of largescale thrust crustal nappes, developed between 390 and $320 \mathrm{Ma}$. The orogen has a fan-like configuration with megafolds and overthrusts facing toward the external Devonian-Carboniferous basins, minor or unrelated to the continental collision. The overthrust is mainly southward in the inner zones of the orogen. The "Central Iberian Zone" in the Iberian Peninsula and in France, represents these inner zones by the South Armorican Zone and Massif Central.

Most of the pre-Mesozoic basement of western Europe is composed of Proterozoic to Carboniferous terranes, which were highly deformed, metamorphosed and intruded by numerous granitoids of various types and sizes (Ribeiro et al. 1979) before the Permian, during the Hercynian orogeny. On the basis of numerous modern structural, petrological, geochemical, geophysical and geochronological studies, it is now possible to reconstruct a relatively continuous Variscan belt (3000 km long and 700 to $800 \mathrm{~km}$ wide), which extends from Morocco to north Bohemia (Matte 1986, 1991). The southern part of the belt was more or less obliterated by younger Alpine deformations. Two granulitic events (the first with high-P characteristics, the second mainly with high-T features) are associated with the successive phases of the subduction-collision of the two plates (Burg et al. 1984). The tectono-metamorphic record in Massif Central and Iberian Peninsula shows that the geological history must involve significant crustal thickening explained by the overthrusting of thick nappes of terranes metamorphosed prior to their thrusting.

Radiometric dating show that there is an almost continuous magmatic activity from Middle-Upper Devonian to Stephanian and Permian. A voluminous magmatism (mainly granitic in composition) was associated with all phases of plate convergence and collision. Magmatic diversity and granitoid distribution imply the involvement of variable crustal sources. Those granitoids are markers of the crustal deformations, indicating their geometrical and kinematic characteristics. Three main stages of granitoid genesis and setting were recognized. The first stage is coeval with the syn-collision thickening of the lithospheric crust through thrusting (compressive style). The second stage (the most important in volume) corresponds to the thermal relaxation, crustal thinning and wrench faulting. The third stage (late to post erogenic magmatism) corresponds to the adiabatic decompression in an extensional regime (Stussi 1989, Lagarde et al. 1992).

In the NW of the Iberian Peninsula, three main phases of deformation D1, D2 and D3 are usually considered as responsible for the framework of this part of the Hercynian belt, the last one being Westphalian in age (Noronha et al. 1981). An important magmatism, essentially represented by voluminous synorogenic granitic plutons, is the marker of the main deformation. The climax of regional metamorphism is syn-to late-D2 and corresponded to a low-pressure, high-temperature regime.

Based on their geological, petrographic and geochemical characteristics, the synorogenic granites are broadly divided into two main groups: two mica granites and biotite granites (Ferreira et al. 1987). The first group of granites could be considered as syn-collisional, approximately syntectonic to D3 (315 - $310 \mathrm{Ma})$. These two-mica granites are generally leucocratic, with biotite and primary muscovite, where modal $\%$ muscovite $>$ or $\gg$ modal $\%$ biotite. They are considered to have resulted from the crystallization of wet peraluminous magmas originated at a mesocrustal level (related with metamorphic processes). The second group of granitoids (biotite granites) is posterior to the climax of the metamorphism. They can be pre-to syn-D3 $(320-315 \mathrm{Ma})$, late-to post-tectonic (310 to $305 \mathrm{Ma})$, or post-tectonic (290 Ma). The biotite granites are considered as having originated at a deep crustal level from relatively dry parental magmas. These granites can be found associated with tonalites and granites with some secondary muscovite.

The nature of the related mineralization is consistent with the petrological and geochemical types of granitoids (Stussi 1989). Some disseminated mineralizations are related to specialized- or fertile- two mica or muscovite leucogranites (Tischendorf 1977). They can present a significant enrichment (up to economic concentrations) in lithophile elements ( $\mathrm{Rb}, \mathrm{Cs}, \mathrm{Li}, \mathrm{F}, \mathrm{Be}, \mathrm{Nb}$, Ta but rarely $\mathrm{W})$ with a strong correlation with ultimate differentiated terms (aplites, pegmatites, and specialized cupolas). The aim of this study is to discuss the origin of the specialization, in terms of mineralogy and chemistry, of evolved granitic and pegmatitic plutons from the Hercynian belt of France and Portugal, concerning the primary or superimposed origin of the mineralizations.

\section{BEAUVOIR GRANITE (NORTHERN MASSIF CENTRAL,}

FRANCE) The Beauvoir granite is a small sheet-like (500 m thick) pluton, flanking the southern border of the Colettes cordierite two mica granite. Both units, as well as the concealed La Bosse granite form the late Hercynian composite Echassieres leucogranitic complex. This complex is intruded in an antiformal tectonic window of micaschists, which is part of the Sioule metamorphic series. Two HT-MP tectonometamorphic events are recognized: the older event is Devonian in age $(400-350 \mathrm{Ma})$ and is marked by a west-verging tangential tectonics; the younger one corresponds to a dextral wrench thrusting. The Beauvoir granite occurs as a small stock and was extensively studied through the deep drilling project GPF1 (Cuney et al. 1992). All the det alled petrographic, structural and geochemical studies of the GPF drill core indicate a multistage intrusion of the Beauvoir granite. Three magma batches, named $\mathrm{B} 3$ to $\mathrm{B} 1$ from bottom to top are petrographically and chemically defined and have an age of $308 \mathrm{Ma}$ $\left({ }^{40} \mathrm{Ar}{ }^{39} \mathrm{Ar}\right.$ on lepidolite; Cheilletz et al. 1992). The apical part of the pluton (B1 fades) has the mineralogy (but not the fabric) of a rare-metal pegmatite as a whole, with mineralization in $\mathrm{Sn}, \mathrm{Li}, \mathrm{Rb}, \mathrm{Nb}, \mathrm{Ta}, \mathrm{Be}$, $\mathrm{F}, \mathrm{P}$, disseminated in the major and accessory phases. The upper Bl fades is hololeucocratic, mainly composed of interlocked laths of albite (40 to $70 \%$ in volume) forming a reticulate framework filled with late globular quartz (15 to $20 \%)$ and interstitial nonperthitic K-feldspar (5 to $10 \%$ ). Silverish lepidolite (5.82 to $6.33 \mathrm{wt} \% \mathrm{Li}, 0$, 7.80 to $8.36 \mathrm{wt} \% \mathrm{~F}, 1.72$ to $1.86 \mathrm{wt} \% \mathrm{Rb}_{2} \mathrm{O}, 0.19$ to $0.26 \mathrm{wt} \% \mathrm{Cs}_{2} \mathrm{O}$ ) is scattered throughout the fades, sometimes observed as radiate aggregates or accumulated in primary layering. Topaz (1 to $5 \%$ ), as rounded crystals is also scattered found. A second generation of topaz 
occurs as small crystals, in girdles between the albite laths. Amblygonite, as strongly altered crystals, is quite abundant. Small octahedral cassiterite is mainly associated with lepidolite. Several generations of apatite can be recognized: a primary Mn-rich accessory phase, or secondarily grown on albite. Pyrochlore-group minerals are well represented in the upper Bl facies (Ohnenstetter \& Piantone 1992).

Although petrographic observations and stable isotope variations (Fouillac \& Rossi 1991) indicate some subsolidus modification of the primary magmatic mineralogy and texture, the Beauvoir granite, even in its more evolved $\mathrm{B} 1$ apical portion, is thought to reflect a magmatic, rather than a metasomatic event (Cuney et al. 1992, Raimbault et al. 1995).
MONTEBRAS GRANITE (NORTHERN MASSIF CENTRAL,

FRANCE) The Montebras granite occurs in the Aigurande Plateau. This thrust nappe inverted tectonics originated from the tectonic superposition, from bottom to top, of micaschists, mixed gneisses and amphibolites, then migmatites. Several telescoped aluminous-to peraluminous- two mica granites, Hercynian in age, constitute an alignment (the eastern Marche peraluminous leucogranite complex). This is bordered to the north by a nearly EW deep wrench fault, the dislocation of la Marche, a major tectonic element of the regional geology.

The Montebras pluton is a small specialized albite granite, which presents similar characteristics as those of the Beauvoir granite. This

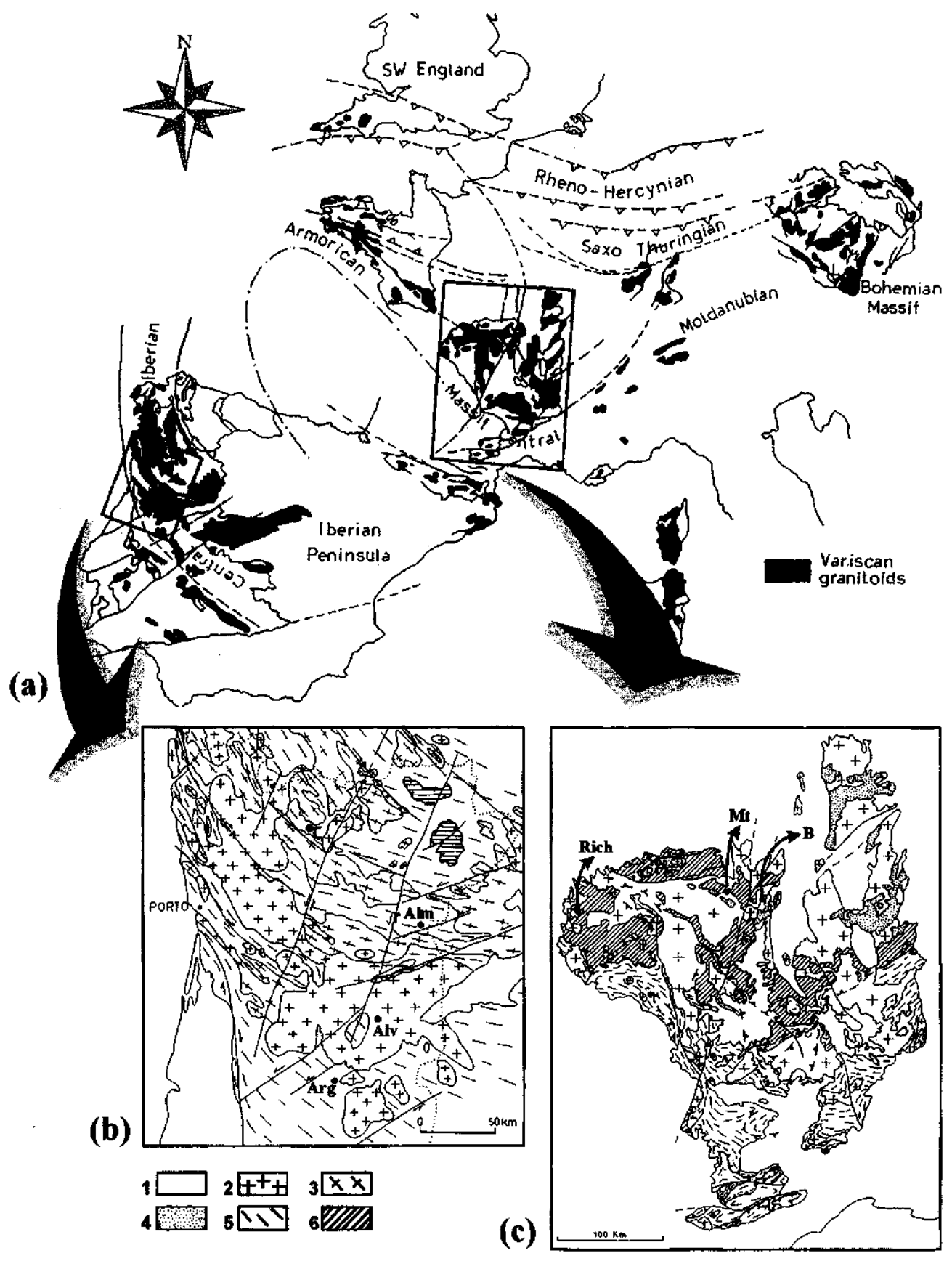

Figure 1 - (a) Geotectonic zones from Western Europe and geological sketch maps from (b) northern Portugal and (c) massif Central (France) (after Matte 1986, Ferreiraet al. 1987 and Bur get al. 1984, simplified). Legende: 1-Post-Variscan cover; 2- Variscan granitoids (biotite granites in N.Portugal); 3- Variscan granitoids (two-mica granites in N Portugal); 4- Lower Carboniferous sediments; 5- Parautochthonous terrains in the massif Central and autochthonous and parautochthonous terrains in N. Portugal; 6- Crystalline nappes. C-Covas; Alm-Almendra; AlvAlvarrões; Arg-Argemela; Rich-Richemont; Mt-Montebras; B-Beauvoir. 
volumetrically small, rare met al-bearing pluton was studied in det all thirty years ago (Aubert 1969) but, since then, its study was forgoten, even though the name montebrasite (a Li-rich phosphate) originates from this locality, where it was first described. A large portion of the granite is kaolinized (from both hydrothermal imprint and weathering) and clays are actively exploited, together with micas, quartz and cassiterite as by-products. The bulk geometry of the albite granite is only known by drilling. It appears as a continuous sheet emplaced between a central small apex of microgranite and the Chanon coarsegrained two mica (biotite » muscovite) granite. The albite granite invades and corrodes both the Chanon granite (roof) and the microgranite (floor). Numerous angulous enclaves (magmatic breccia, cauldron subsidence, magmatic sloping ?) of the Chanon granite are found in the Montebras albite granite, which forms an interstitial matrix. Rounded enclaves of greisen-like rocks are also frequently encountered. A pegmatite differentiate (stockscheider) forms a thin (rarely > $1 \mathrm{~m}$ thick) marginal rim at the upper contact with the Chanon granite. The Montebras albite granite is composed of albite $(30-50 \mathrm{wt} \%)$ quartz $(20-30 \mathrm{wt} \%)$, microcline $(5-30 \mathrm{wt} \%)$ and muscovite $(5-10$ $\mathrm{wt} \%)$ as major phases, and Mn-rich apatite, topaz, cassiterite, columbite and amblygonite as accessories. Albite and muscovite are early crystallized in the sequence and quartz has a corroding behavior. This granite cannot be interpreted of metasomatic origin (as exemplified by the apogranites of the Soviet scientists; e.g. Kovalenko et al. 1970) but is a real magmatic complex (Aubert 1969).

RICHEMONT RHYOLITE (WESTERN MASSIF CENTRAL, FRANCE) The Richemont rhyolite occurs as a $5 \mathrm{~km}$ long, $6 \mathrm{~m}$ wide dike, that sharply crosscuts Devonian amphibolites and felsic gneisses, and older biotite granites. It is striking NS, roughly perpendicular to the EW elongation of the Blond two-mica granite with which it is supposed to be related. Numerous small W-Sn occurrences are marginally distributed around the granite or closely associated with the dike. Whole-rock $\mathrm{Rb}-\mathrm{Sr}$ isochron indicate an age of $301 \pm 5 \mathrm{Ma}$ for the Blond granite (Duthou 1977).

Mineralogical and chemical features presented by the Richemont rhyolite dike evidence its close relationship with rare-element pegmatites of the LCT type (Cerny 1992). Data about this special occurrence are rather scarce in the French literature (Burnol 1974, Raimbault \& Burnol submitted). The main texture of the rhyolite is nearly aphanitic with only $4-5 \%$ in volume of phenocrysts. These are small euhedral phenocrysts $(<2 \mathrm{~mm}$, averaging $0.6 \mathrm{~mm})$ and include albite $(49-56 \%)$, quartz (20\%), K-feldspar (15-22\%) and muscovite (10\%). Chilled margins with a banded texture with abundant phenocrysts are present all along the exposure of the dike. The inclusion principle reveals the following crystallization order: feldspar (albite in first), muscovite and, then, quartz.

Exotic rounded aggregates of phosphates (mainly Mn-rich apatite, triplite, amblygonite) associated with ore minerals (lollingite, W-Nb oxide, scheelite, cassiterite \pm wolframite, tennantite-tetrahedrite) are present in close association with muscovite phenocrysts. These ore minerals appear also scattered within the aphanitic groundmass. Such aggregates (bubbles?) of exotic minerals, frequently encountered as accessories in evolved pegmatites, are thought to result from immiscibility during quenching of the rhyolite magma (ebullition-unmixing process at the late magmatic stage ? Webster et al. 1997).

Recrystallization of the matrix of the rhyolite, thought to be formerly glassy, is frequent in a fine-grained (10-20 m?) mixture of quartz and feldspar, with radiate rosettes of white mica $(150 \mathrm{~m}$ ? in diameter) supposed to be lepidolite. Numerous thin quartz veinlets with bertrandite (Be-silicate) crosscut the dike. More det alls will be found in Raimbault \& Burnol (submitted).

Most of the petrographic characteristics of the Richmond rhyolite dike are obviously magmatic. The quartz-muscovite $8^{18} \mathrm{O}$ thermometer (Bottinga \& Javoy 1975) yields a temperature of $540 \pm 50^{\circ} \mathrm{C}$, which is consistent with the low solidus temperature $\left(560-580^{\circ} \mathrm{C}\right)$ inferred for such highly evolved F-rich melts (Pichavant et al. 1987).

\section{ARGEMELA MICROGRANITE (CENTRAL PORTUGAL)}

The Argemela microgranite (AMG) is a small elliptical pluton intruded in low-grade (chlorite zone) metamorphic schist-greywackes of the Beira Group (part of the Durico-Beirao Supergroup "Complexo XistoGrauvaquico", Precambrian to Cambrian in age) in Central Portugal. A few kilometers northwards, the large and composite (mainly two mica) late-tectonic Serra da Estrela batholith crops out and possibly extends, beyond faulting, beneath the Argemela district.

Because of its small size and the reduced volume of fluids exsolved, much of the primary paragenesis of the pluton was preserved. This is an uncommon feature once such rare-element specialized plutons where widespread subsolidus alteration is the rule and for which the rare-element "status" is obviously secondarily reached. Petrology of this small porphyritic pluton has been described in det all and modeled in a recent paper (Charoy \& Noronha 1996). The genetic model is bimodal, proposed to be a mechanical mixture of an early aplitic material present as feeders (mainly composed of albite, quartz and phengite) and a "lubricant", which allowed its ascent high in the crust. This lubricant crystallized in situ and was responsible for the rare-element and volatile anomalies ( $\mathrm{Sn}, \mathrm{Li}, \mathrm{Be}, \mathrm{Rb}, \mathrm{F}, \mathrm{P}, \ldots$... $\mathrm{K}$-feldspar is absent in the magmatic paragenesis.

Contrary to most of the rare-eleOment pegmatites, the AMG is texturally and chemically very homogeneous in terms of major elements. The microgranite is strongly peraluminous and $\mathrm{Na}$-rich; its $\mathrm{Li}$ and $\mathrm{F}$ contents are high, in accordance with the particular paragenesis. Silica content is quite low, commonly $>70 \mathrm{wt} \%$. Lithium is positively correlated with $\mathrm{F}$ and $\mathrm{Rb}$. Beryllium and tin contents are high, due to the occurrence of disseminated beryl and cassiterite. AMG offers a special opportunity to monitor the evolution of $\mathrm{Li}$ at magmatic and subsolidus stages through the record offered by its Li-rich micas. Lithium content is still high even after amblygonite subtraction (assuming P-Li stoichiometry), suggesting that some Li-rich mica phase is present. Ion and electron microprobe investigations were conducted in order to detect quantitative change in major elements, including $\mathrm{Li}$, across the zoned mica crystals and aggregates (Charoy et al. 1995).

In spite of the chemical homogeneity of the AMG, several lines of evidence, including petrography and inferred paragenetic sequence, suggest that at least two steps of growth characterize the progressive crystallization of the magma. The second step records the compositional differentiation of the pluton, with strong enrichment in $\mathrm{Li}, \mathrm{P}, \mathrm{Be}$, $\mathrm{Sn}, \mathrm{P}$ and $\mathrm{F}$. The primary phengite was in disequilibrium with such a medium, which resulted in its replacement by lepidolite (3.88 - 4:60 wt $\% \mathrm{Li}_{2} \mathrm{O}, 5.25-5.79$ wt $\%$ F, $1.26-1.50$ wt $\% \mathrm{Rb}_{2} \mathrm{O}, 0.12$ wt $\left.\% \mathrm{Cs}_{2} \mathrm{O}\right)$. Disequilibrium was in large scale because there was no intermediate compositions. It seems also evident that the necessary conditions for lepidolite stability prevail during a relatively short period of time, because of the occurrence of late tiny flakes of muscovite (phengitic in composition), which occur around mica flakes, on albite and throughout the matrix of the AMG. These features correspond to a classic sericitic alteration.

Most of the characteristics of the Argemela system are assumed to be mainly magmatic and resulted from the rapid ascent of the mixture (a mush of primary crystals and the lubricant), allowing to infer an evolution, in time and space, similar to what is found in the interior of zoned rare-element pegmatite plutons.

ALVARRÕES PEGMATITE (CENTRAL PORTUGAL) SeVeral aplite-pegmatite sills of variable size crosscut the late-tectonic biotite granites that are part of the Serra da Estrela batholith. All pegmatites are granitic in composition but one can distinguish three types of sills, presumably related to the structural level (Ramos et al. 1995). The Li-rich sills (higher in the structure) can be macroscopically distinguished by their typical violet color. Petrographic study reveals a succession of different overprinting stages: the earlier, corresponding to the pegmatitic texture, is essentially characterized by quartz, Li-muscovite, albite, and $\mathrm{K}$ feldspar, with some topaz and amblygonite. The later, mainly sodolithic, has an aplitic texture, characterized by presence of lepidolite (5.30 -5.90 wt $\% \mathrm{Li}_{2} \mathrm{O}, 7-9 \mathrm{wt} \% \mathrm{~F}, 0.98-1.26 \mathrm{wt} \%$ $\mathrm{Rb}_{2} \mathrm{O}, 0.15 \mathrm{wt} \% \mathrm{Cs}_{2} \mathrm{O}$ ), albite and quartz. Cassiterite is a common accessory phase.

A fluid-inclusion study (Ramos \& Noronha 1995) has been performed on quartz, lepidolite, albite and topaz from the later stages of these Li-rich sills. Fluids contemporaneous with the formation of these minerals (data from primary and pseudosecondary inclusions) were homogeneous, aqueous with a low salinity $(<8.5 \mathrm{wt} \%$ eq $\mathrm{NaCl}) . \mathrm{CO}_{2}$ was detected, neither with microthermometric, crushing nor Raman studies. Homogenization to the liquid phase occured in the $160-260^{\circ} \mathrm{C}$ range with two peaks at $210^{\circ} \mathrm{C}$ and $250^{\circ} \mathrm{C}$. These data suggest that the main episode of lepidolite formation occurred around $300^{\circ} \mathrm{C}$, and 100 $\mathrm{MPa}$.

\section{ALMENDRA PEGMATITE (NORTHEASTERN PORTUGAL)}

The Almendra is a pluton similar to the Alvarrões pegmatite is terms of evolution. It is a classical pegmatite dike (about $200 \mathrm{~m}$ long and $5 \mathrm{~m}$ thick), intruded into low grade (chlorite zone) metamorphic schistgreywackes of the Douro Group (part of the Durico-Beirao Supergroup "Complexo Xisto-Grauvaquico", Precambrian to Cambrian in age), 2 $\mathrm{km}$ northwards of a syntectonic two-mica granitic massif. 
The paragenesis of the pegmatite is largely dominated by pink lepidolite (as centimetric crystals or in fine-grained aggregates) and cleavelandite. Topaz is marginally corroded; amblygonite is replaced by secondary phosphates and lepidolite. This paragenesis, which is symptomatic of the sodolithic pegmatites, is obviously secondary after primary K-feldspar. There is no remnant, as in the Alvarrões pegmatite, of any primary Li-mineralization, which apparently was entirely consumed. Some of the aplite-pegmatite material hosts a low-grade tin mineralization

COVAS DE BARROSO DISTRICT (NORTHERN PORTU-

GAL) The Covas do Barroso district is characterized by countless granitic aplite-pegmatite dikes and aplite veins, which sharply crosscut metasediments of Silurian age. These are affected by the three episodes of regional deformation, the maximum metamorphic conditions corresponding to the andalusite zone. Different types of granites, all of Hercynian age, are found in the area. The syntectonic two-mica granites are dominant in the district, where they define two large NW-trending structures, which broadly correspond to the core of D3 antiforms. The aplite-pegmatite bodies range from concordant to highly discordant, but all are more or less deformed. The majority of the aplite-pegmatite dikes is fracture (linear or en echelon) controlled. Brittle deformation, "boudinage", lineation and even folding, is statistically related to that of the enclosing metasediments, and is supposed to have been generated during the D3 compression phase. Many of the aplite veins host a low-grade tin mineralization $(0.1-0.3 \mathrm{wt} \%$ of cassiterite) and were mined at a small scale after the second world war.

All pegmatites are granitic in composition but some of them present valuable Li-mineralization such as spodumene (Charoy et al. 1992). Some of these show widespread subsolidus alteration to pet alite, secondary albite and K-feldspar, eucryptite and muscovite. Spodumene can sometimes be entirely pseudomorphically replaced by white mica $\left(0.13 \mathrm{wt} \% \mathrm{Li}_{2} \mathrm{O}\right)$ and $\mathrm{Li}$ is partly to totally leached out from the system. When compared to the Li content in dikes apparently devoid of any subsolidus alteration, $\mathrm{Li}$ is divided at least two times. A narrow anomalous Li-rich halo is sometimes present in the enclosing schists.

The occurrences studied in the Covas de Barroso district have a relatively simple paragenesis: albite is frequently the only feldspathic phase in the aplite units; alkali feldspar is sometimes present as late stage, interstitial, weakly perthitic crystals; phengite $\left(0.13 \mathrm{wt} \% \mathrm{Li}_{2} \mathrm{O}\right.$, $\left.0.12 \mathrm{wt} \% \mathrm{~F}, 0.02 \mathrm{wt} \% \mathrm{Rb}_{2} \mathrm{O}\right)$ is largely dominant over biotite, minor tourmaline (schorl) and/or spessartine-rich garnet.

In contrast, the pegmatite units are dominated by poorly perthitic alkali-feldspar megacrysts, which locally display a branching habit or a brush-like distribution, growing either on aplite floors or on finegrained tourmaline/garnet-rich layers, sometimes in radiate aggregates. K-feldspars are obviously of several generations. A F-poor phosphate of the amblygonite series occurs in both aplites and pegmatites, but is generally rare and highly altered. Spodumene occurs mainly in the pegmatitic part, however it can be present in some aplitic units (Charoy et al. 1992). Associated aplite and pegmatite doublets are roughly identical in composition, except for alkalis, with a higher $\mathrm{Na}$ content in the aplites, reflecting the presence of albite as the only (or largely dominant) feldspar. In the aplites, $\mathrm{K}$ is mainly hosted by micas. This is in accordance with the model of Jahns .\& Burnham (1969) for alkali partitioning for aplite-pegmatite pairs. Fluorine content is always low.

A fluid-inclusion study (Doria et al. 1989) has been performed on some of these Portuguese spodumene-bearing pegmatites. Results on spodumene and presumably coexisting quartz would help to constrain some possible physical parameters about their genesis. Fluids contemporaneous with spodumene precipitation (data from primary and pseudosecondary inclusions) were heterogeneous brines of variable density. The volatile component of these fluids in spodumene, and quartz was dominated by low density $\mathrm{H}_{2} \mathrm{O}, \mathrm{CO}_{2}$, with minor but detectable amounts of $\mathrm{CH}_{4}$ and $\mathrm{N}_{2}$ (Raman determination). Homogenization to the liquid or vapor phase occured over the $320-365^{\circ} \mathrm{C}$ range. Virtually, all primary inclusions are crystal-rich with a variable crystal/liquid ratio. A plot of these data in the P-T petrogenetic grid for Li-aluminosilicates proposed by London (1984) constrains the maximum conditions for spodumene precipitation of: $475-530^{\circ} \mathrm{C}$ for a confining pressure of 250 to $300 \mathrm{MPa}$, which is slightly lower than conditions estimated for the peak of regional metamorphism. These results are broadly concordant, in terms of $\mathrm{P}$ and $\mathrm{T}$, with those determined by London (1985 and 1986) for the Tanco pegmatite, even if $\mathrm{CO}_{2}$ is apparently lacking as a volatile component in spodumene. $\mathrm{CO}_{2}$ was also absent during the evolution of Li-pegmatites from S-E
Ireland (Whitworth \& Rankin 1989). Chakoumakos \& Lumpkin (1990) broadly determine $550^{\circ} \mathrm{C}$ and $330-350 \mathrm{MPa}$ for spodumene precipitation in the Harding pegmatite (with $\mathrm{CO}_{2}$ present).

DISCUSSION Representative chemical data of the above examples are listed in Table 1, together with the chemical composition of the Harding pegmatite (Burnham \& Nekvasil 1986), often chosen as an exemplar representative of rare-element, Li-rich pegmatite class (Cerny 1991). All our samples, except for the Covas de Barroso district have chemical similarities, such as rather low silica $(<70 \mathrm{wt} \%)$ and very high Na contents. They present, except for the spodumene-bearing pegmatites of the Covas de Barroso district, a $\mathrm{Na} / \mathrm{K}$ ratio $» 1$, reflecting the large dominance of albite on K-feldspar (K-feldspar being even absent at the Argemela pluton). $\mathrm{Ca}, \mathrm{Fe}$ and $\mathrm{Mg}$ contents are always very low, whereas $\mathrm{P}$ content can be very high; $\mathrm{F}$, excepted for spodumene pegmatites of the Covas de Barroso district, is also high. Both aplite and pegmatite units are strongly peraluminous, as the $\mathrm{A} / \mathrm{CNK}$ (aluminium saturation index $=$ mole $\mathrm{Al}_{2} \mathrm{O}_{3} /\left(\mathrm{CaO}+\mathrm{Na}_{2} \mathrm{O}+\mathrm{K}_{2} \mathrm{O}\right)$ ) 1.3 . $\mathrm{Be}$ content is generally high ( $\mathrm{Be}$ found in beryl or phosphates).

There is unequivocal evidence that these residual magmas were saturated with respect to cassiterite prior to complete consolidation, suggesting some oxidizing conditions (Linnen et al. 1995). These data, together with that of Stewart (1978) are plotted in the normative (wt\%) quartz-combined feldspars-eucryptite triangular plot (Fig. 2). Data scatter widely into the triangular plot quartz-feldspars-pet alite as already outlined with some confidence by Stewart (op. cit.), which demonstrates the large variation in all three virtual components for all available pegmatite compositions. However, most of these "representative" compositions are highly questionable and will rarely represent a true magmatic composition (London et al. 1989), the only exception being the Macusani glass (Pichavant et al. 1988) and the Richemont rhyolite (Raimbault \& Burnol, submitted)

Jahns (1953) admitted the misleading character of the whole-rock chemical compositions given in the literature as representative of these complex liquids. Extreme compositions (close to the Q apex) are obviously representative of Q-rich, (lithium-aluminosilicate) differentiates, and regarded as very late residual melts (London 1990). Many of the Li-rich pegmatites present a quite large Q-feldspars distribution: $\mathrm{Q}$ in the $20-50 \%$ and feldspars (mainly $\mathrm{Ab}$ ) in the $30-70 \%$ range. Percentage of eucrytite is narrower, between 5 and $20 \%$. If most of them are Ab-rich (the inevitable sodolithic imprint), some (i.e. primitive spodumene pegmatites ?) venture to present a real granitic signature. The fact that many pegmatites as a whole, deviate significantly from a granitic composition would signify that a certain proportion of elements were added to the system (London 1990).

Many authors believe that crystallization of a F-rich peraluminous magma can produce extreme enrichment in incompatible elements in highly evolved residues. Volatiles such as F, P enhance the migration of projected residual melt compositions towards the $\mathrm{Ab}$ apex (Manning 1981, London 1987). But what about those with a more granitic (potassic) composition? If there is a real "attraction" to a sodic composition for these Li-rich liquids, this was often reached through a more or less important subsolidus reworking of the primary paragenesis. Albite forms large and nearly ubiquitous segregations in many pegmatites, as fine-grained saccharoidal aplites or radial coarse-grained, obviously late-crystallized cleavelandite. In the AlvarrSes and Almendra aplite-pegmatite dikes, there are conspicuous evidence of replacement of much of the former paragenesis by albite (cleavelandite) and corroding aggregates of fine-grained, deep-purple lepidolite. London (1990) regards these aplitic units as primary and non replaceable, and would correspond to a restitic melt of alkaline, sodic composition, as suggested by experiments with Macusani glass. The absence of unequivocal evidence of vapor saturation marks the lack of a vapor-free expression in some of these residual systems.

Recent experiments demonstrated that a pegmatitic fabric can be obtained in undersaturated conditions (London et al. 1989) and vapor/melt partition coefficients for most rare-elements are «1 and often approach values of 0.0 (London 1990). He concludes his synthesis about internal differentiation of pegmatites that, contrary to what affirmed (and widely accepted) by Jahns \& Burnham (1969), Burnham \& Nekvasil (1986), the role of an aqueous phase is of secondary importance and has only a nominal affect on zoning and fabric organization. The exsolved aqueous vapor, also chemically alkaline, would be very reactive and would promote some widespread metasomatic alteration of adjacent Li-minerals (exchange operator $\mathrm{NaLi}-1$ ). This vapor would evolve towards a more acidic character, reacting with the former silicates in order to converting them into mica aggregates, obviously replaceable in texture. This process would originate the late 
Table 1 - Representative chemical data of the studied examples.

\begin{tabular}{|c|c|c|c|c|c|c|c|c|}
\hline & Besuvoir & Mountebras & $\begin{array}{c}\text { Richenrout } \\
\text { LI4C3 }\end{array}$ & $\begin{array}{l}\text { Argenueda } \\
\text { ARGE 18A }\end{array}$ & Alemindra & Alvarrōes & $\begin{array}{c}\text { Cavas } \\
\text { Burrossa } \\
\text { CHN-5 }\end{array}$ & Marding \\
\hline & (t) & (2) & (3) & (4) & (5) & (5) & (6) & (7) \\
\hline $\mathrm{SiO} 2$ & 67.7 & 72.9 & 69.43 & 68.42 & 69.57 & 68.56 & 73.25 & 75.24 \\
\hline A|2O3 & 17.4 & 16.58 & 16.35 & 18.53 & 17.35 & 19.11 & 16.14 & 14,42 \\
\hline $\mathrm{Fe} 203$ & & 0.28 & & & & & & 0.12 \\
\hline $\mathrm{FeO}$ & & 0.13 & & & & & & 10.35 \\
\hline Fe203t & 0.25 & & 0.59 & 0.32 & 0.16 & (1).04 & 0.81 & \\
\hline MnO & 0.03 & 0.06 & 0.11 & 0.06 & 0.05 & 10.11 & 0.04 & 0.18 \\
\hline $\mathrm{MgO}$ & 0.03 & 0.05 & 0.01 & tr. & t. & 0,02 & 0.15 & 0.01 \\
\hline $\mathrm{CaO}$ & 0.54 & 0.5 & 1.03 & 0.05 & 0.3 & 0.2 & 0.19 & 0.2 \\
\hline $\mathrm{Na} 2 \mathrm{O}$ & 4.84 & 4.3 & 3.89 & 5.94 & 9.05 & 4.08 & 2.45 & 4.23 \\
\hline k20 & 3.31 & 3.9 & 3.1 & 2.54 & 3.25 & 3.75 & 3.54 & 2.74 \\
\hline P205 & 1.45 & 0.34 & 1.18 & 1.43 & 0.73 & 0.65 & 0.4 & 0.13 \\
\hline $\mathrm{F}$ & $1.45-2.70$ & 0.21 & 1.28 & 8.06 & 1.33 & 2.92 & 0.03 & 0.64 \\
\hline Lot & variathk: & 1.66 & 2.15 & $2 .(29)$ & 2.34 & 3.03 & 2.12 & nd \\
\hline$O=F$ & $0.61-1.14$ & $0 .(99$ & 0.76 & 0.45 & 0.56 & 1.23 & 0.01 & 0.27 \\
\hline toxal & & $1(x) .82$ & 98.36 & 99.94 & 99.57 & 101.24 & 99.131 & \\
\hline Li & $\$ 810$ & \$380 & 3200 & $4(122$ & 4960 & 9770 & 6270 & 3033 \\
\hline Rb & 3650 & 1737 & $1 \times 006$ & 21106 & 2570 & 3198 & 770 & 1737 \\
\hline Cis & 423 & no & $2 \times 3$ & 214 & 4.30) & nd & noll. & 472 \\
\hline Bc. & 168 & 3 & 90 & 126 & $2(x)$ & 334 & $\mathrm{ml}^{\circ}$ & nd \\
\hline Sn & 1330 & 1430 & 490) & 653 & 0.55 & 320 & 4.5 & and \\
\hline A/CNK & 1.39 & 1.37 & 1.65 & 1.46 & 1.410 & 1.72 & 1.45 & 1.39 \\
\hline $\mathrm{N} 2 \mathrm{~K}$ & 2.22 & 1.68 & $1 . \%)$ & 3.55 & 2.36 & 1.66 & L.1.6 & 2,32 \\
\hline
\end{tabular}

"lepidolitization" stage, if $\mathrm{F}$ is added (or available) to the system, due to the breakdown of fluorine complexes.

This scenario could be advocated for the Almendra and Alvarrões sodolithic pegmatites, but not for the Beauvoir and Argemela plutons. In these two latter, both albite (largely dominant) and lepidolite are obviously of primary origin. In most of the studied spodumene-rich, aplite-pegmatite bodies, fluorine activity (estimated from the $\mathrm{F}$ content in the whole-rock compositions) is low throughout their consolidation and stabilizes Li-aluminosilicate phases instead of lepidolite (Burt \& London 1982). This is not true for the more evolved aplite-pegmatite bodies where fluorine has a more significant role and stabilizes a lepidolite, topaz and F-rich amblygonite association, together with aggregates of albite (cleavelandite habit). These phases are mainly developed at a subsolidus stage by replacement of an earlier assemblage (alkali feldspar but absence of any relict primary spodumene at the Alvarrões or Almendra plutons).

The occurrence of lepidolite as overgrowth on phengite at the Argemela pluton seems to be controlled by several factors additional to the mere availability of $\mathrm{Li}$ (and F) in the system. Coupling between $\mathrm{Li}$ and $\mathrm{F}$ for high Li-contents leading to lepidolite end-members woudl be necessary (Foster 1960, Munoz 1968, Rieder 1970, Monier 1987, Monier \& Robert 1986). This is confirmed by the representative analyses of white micas with contrasting compositions from the foregoing examples (Table 2). In environments where activities of $\mathrm{P}$ and $\mathrm{F}$ are high, all Li-aluminosilicates (spodumene or pet alite) become unstable relative to the amblygonite + quartz assemblage (Burt \& London 1982). Fluorine activity also appears to be determinant in the stabilization of lepidolite, relative to these lithium aluminosilicates (Munoz 1968,1971, London \& Burt 1982). If amblygonite effectively exhausts $\mathrm{F}$ from the pegmatite melt or fluid, lepidolite will not form or in negligible amounts.

Spodumene or pet alite (according to the confining pressure) will occur only in Li-rich pegmatites, which are primarily poor in volatile (F, Na, water?) elements (London 1984). Perhaps $\mathrm{P}$ is the only element susceptible to create some competition between Li-rich phases: spodumene-pet alite and Li-phosphates, whereas in F-rich systems, the stable Li-phase will be lepidolite (or Li-rich muscovite) as encountered in the Beauvoir and Argemela plutons.

A quantitative estimation of the relative proportion of the major phases in a complex zoned pegmatite is very difficult. Because of their complex relationship, it is often an impossible task to distinguish remnants of the primary pegmatite paragenesis from all secondary and replacement products. For example, Jahns (1953) noted the apparent coexistence of spodumene and lepidolite, which, because of the strongly divergent $\mathrm{F}$ activity for their respective stability, cannot be coeval. A high P activity, necessary for the stability of amblygonite, is more or less in disagreement with a high Si activity, specific of the central massive quartz core, frequent in many zoned pegmatites. Disequilibrium is the rule all along the late stages of pegmatite crystallization and will be highly enhanced during subsolidus reworking.
Table 2 - Representative analyses of white micas ( $n$ : number of analyses).

\begin{tabular}{|c|c|c|c|c|c|c|c|c|c|c|}
\hline & $\begin{array}{l}\text { Iicave } \\
\text { vour } \\
\text { (i) }\end{array}$ & $\begin{array}{l}\text { Monte } \\
\text { drras } \\
\text { (2) }\end{array}$ & $\begin{array}{c}\text { Rklhe- } \\
\text { mont } \\
(3)\end{array}$ & & 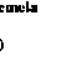 & $\begin{array}{l}\text { Alswen- } \\
\text { dru } \\
\text { (5) }\end{array}$ & $\begin{array}{l}\text { Alvat- } \\
\text { rōes } \\
(6)\end{array}$ & & ras Herre & \\
\hline & & & & $\substack{(n=8) \\
(n=8)}^{2}$ & $\begin{array}{l}\text { cure } \\
\langle n=? \eta\end{array}$ & & $(n=2)$ & $\begin{array}{c}\text { CHN } 5 \\
(a=5 i\end{array}$ & $\begin{array}{c}\mathrm{CHN} 3 \\
(n=7)\end{array}$ & $\begin{array}{l}\text { Alijs } \\
(n=8)\end{array}$ \\
\hline $\mathrm{Si}(1) 2$ & 52.25 & $46.56)$ & $45.6,3$ & 49.10 & 45.75 & $\$ 1.41$ & \$. 1.10 & 45.93 & 46.98 & 46.28 \\
\hline Ti02 & 0.03 & 0.00 & • & $\cdot$ & 0.06 & $\cdot$ & . & $\cdot$ & $\cdot$ & . \\
\hline $\mathrm{Al} 203$ & 22.04 & 25.80 & 33.14 & 28.60 & 35.25 & 24.04 & 25.39 & 38.37 & 37,43 & 37.69 \\
\hline fied & 0.60 & 1.08 & 2.95 & 0.95 & 2.30 & 0.13 & 0.03 & 0.61 & 1.00 & 0.43 \\
\hline MoO & 0.12 & 0.40 & 0.19 & 0.53 & $0.0 \%$ & 0.17 & 0.33 & 0.09 & 0.07 & $\cdot$ \\
\hline $\mathrm{MgO}$ & 0.03 & 0.08 & . & $\cdot$ & 0.05 & 0.01 & 0.01 & 0.01 & . & 0.01 \\
\hline $\mathrm{CaO}$ & 0.08 & $\cdot$ & nd & - & - & - & 0.01 & - & . & $\cdot$ \\
\hline $\mathrm{Na2O}$ & 0.37 & 0.50 & 0.74 & 0.11 & 0.68 & 0.28 & 0.20 & 0.47 & 0.35 & 0.63 \\
\hline $\mathrm{K} 20$ & 9.58 & 11.20 & 10.64 & 10.62 & J0.05 & 10.45 & 10.39 & $\$ 0.19$ & 10.33 & 1072 \\
\hline $\mathrm{Rb} 2 \mathrm{C}$ & 1.79 & $|x|$ & 0.44 & 1.41 & 0.46 & 1.26 & 1.00 & nu & nd & $\mathrm{md}$ \\
\hline Lize & 6.077 & 2.95 & 2.44 & 3.8R & 0.40 & nd & 5.58 & 0.17 & 0.21 & 0.13 \\
\hline F & 8.08 & 2.40 & 2.08 & 5.79 & 1.33 & 7.00 & 7.50 & 0.36 & 0.35 & 0.28 \\
\hline $\mathrm{H} 20$ & 0.69 & 1.80 & 2.44 & od & nd & $\mathrm{ml}$ & 0.60 & sul & nd & ixd \\
\hline (1) & 3.40 & 1.22 & 0.87 & 2.44 & 0.56 & 2.95 & 3.20 & 0.15 & 0.15 & 0.12 \\
\hline$\Sigma$ & 98.3 .3 & 93.05 & 99.82 & 98.55 & 95.86 & 91.81 & 101.10 & 96.04 & 96.63 & 95.59 \\
\hline Si & 6.980 & 6.900 & 6.212 & 6.548 & 6.143 & 3,408 & 6.467 & 6.425 & 6523 & 6.123 \\
\hline Al & 1.020 & $1.2(x)$ & $1.7 \mathrm{~kg}$ & 1AS2 & 1.857 & 0.593 & 1.533 & 1.575 & 1.47 & 1.875 \\
\hline Al & 2.447 & 3.240 & 3522 & 3.033 & 3.713 & 3.482 & 1.249 & 3.791 & 3.721 & 3.910 \\
\hline$\pi$ & 0.004 & 0.004 & . & $\cdot$ & 0.006 & • & • & - & - & - \\
\hline Fe & 0.064 & 0.132 & 0.335 & 0.104 & 0.258 & 0.017 & . & 0.067 & 0.125 & 0.048 \\
\hline $\mathrm{Mn}$ & 0.016 & 0.053 & 0.024 & 0.056 & 0.008 & 0.017 & 0.039 & 0.008 & 0.008 & . \\
\hline$M g$ & 0.008 & 0.017 & - & . & 0.010 & . & $\cdot$ & . & $\cdot$ & - \\
\hline Li & 3.253 & 1,720 & 1.323 & $2.0 \times 4$ & 0.209 & nd & 2.82 .5 & 0.101 & 0.117 & 0.064 \\
\hline$N_{2}$ & 0.096 & 0.140 & 0.146 & 0.032 & $\operatorname{t.n}$ & 0.069 & 0.061 & 0.134 & 0.100 & 0.159 \\
\hline K & 1.6 .35 & $\cdot$ & 1.846 & L.ROB & 1.724 & 1.919 & 1.671 & 1.813 & 1.833 & 1.810 \\
\hline kh & 0.1000 & 2.088 & 0,033 & 0.128 & 0.032 & 0.121 & 0.076 & $\cdot$ & - & . \\
\hline$F$ & $3.40 \mathrm{I}$ & 1.342 & 0.890 & 2.55 & 0.58 & 3.08 & 3.038 & 0.16 & 0.16 & 0.12 \\
\hline$O H$ & 0.430 & 1.755 & 2.206 & 1.45 & 3.42 & 0.92 & 0.501 & 3.84 & 3.84 & 3.88 \\
\hline
\end{tabular}

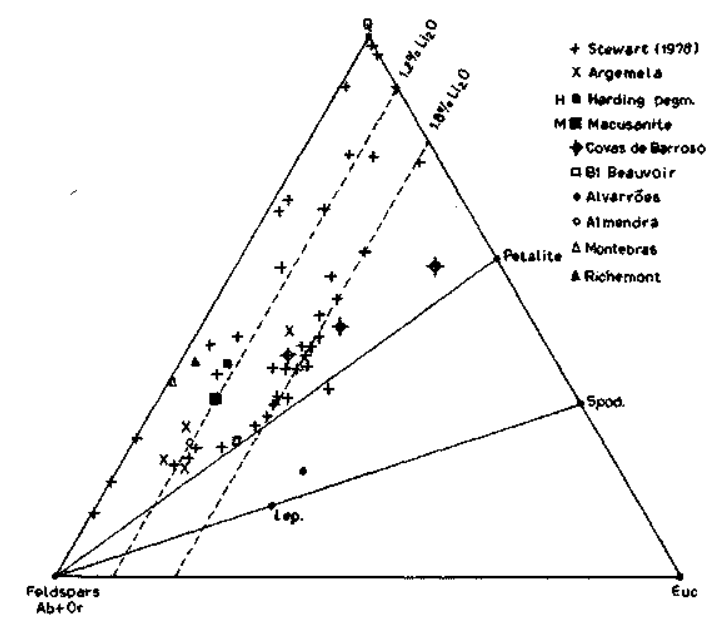

Figure 2 - Quartz-combined feldspars-eucryptite triangle (completed from Stewart 1978).

Alternative mechanisms for describing and, explaining, all replacement features in pegmatites bespeak open system conditions with introduction of fluids from outside. This is assumed to explain the unusual high $\mathrm{Sr}$ content (up to $500 \mathrm{ppm}$ ) of the Beauvoir granite; $\mathrm{Sr}$ is essentially hosted in a secondary phosphate (goyazite) grown on albite. The $\mathrm{Sr}$ isotopic composition of goyazite confirms its external origin from the enclosing metamorphic rocks (Charoy et al. submitted). Large metasomatic haloes developed in the close surroundings of some of examples described in this paper (cf Beauvoir granite, in Aubert 1969) postulate for such exchanges with enclosing country rocks.

CONCLUSIONS All of the above examples are representative of the highly evolved, rare-element rich, pegmatite class. Some of them have obviously reached their specialized status at the magmatic stage and lithium is hosted by the major primary minerals (lepidolite and amblygonite at the Beauvoir granite, spodumene at the Covas de Barroso district). For the other studied plutons, features are indicative of a secondary, replaceable (metasomatic) origin. Vapor saturation (exsolution) will be a near-solidus event, with the coeval precipitation 
of an ore-bearing albite-mica mixture and alteration of the primary pegmatite assemblage. These evolved granitic plutons have a common mode of origin, regardless to the extent of their geological setting. All the foregoing examples are volumetrically very small, implying batches of magma of very restricted size due to either a reduced melting fraction of a crustal source with a very restricted composition, or a late

The real significance of the highly exotic compositions of these rare-element, Li-rich pegmatites (or equivalents) remains undefined, because spatial and genetic evidence of relationships with a larger withdraw of a residual liquid.

magmatic pluton are often lacking. Importance, complexity and duration of their subsolidus reworking, volume of exchanges with the exterior are highly variable from one case to another. It is very difficult to explain all differences shown by these evolved bodies by a simple and single modeling, and conclusions remain ambiguous and controversial.

Acknowledgements This work was supported by a contract JNICT (Portugal)-MESR (France) "Reseau de Formation et Recherche" RFR 38/96.

\section{References}

Aubcrt, G. 1969. Lcs coupolcs granitiqucs dc Monlcbras et d'Echassifères (Massif Central fransais) ct la genfese de Icurs mindralisalions en $<5$ lain, lithium, tungstcne et béryllium. Mémoire BRGM, 46, 345pp.

Bottinga, Y. \& Javoy, M. 1975. Oxygen isotope partitionning among the minerls in igneous and metamorphic rocks. Rev. Geoph. Space Physi, 13:401-418.

Burg, J.P., Leyrcloup, A., Marchand, J., Matte, P. 1984. Inverted mctamorphic zonalion and large-scale thrusting in the Variscan Belt: an example in the French Massif Central. In Variscan Tectonics of the North Atlantic Region. D.H.W. Hulton \& D.J. Sanderson (cds). Geol. Soc., Spec. Public. 14:47-61.

Burnham, C.W. \& Nckvasil, H. 1986. Equilibrium properties of granitic pegmatite melts. Amer. Mineral., 71, 239-263.

Burnol, L. 1974. Gdochimic du bdryllium ct types de concentration dans Ics leucogranitcs du Massif Central francais. Memoire BRGM, 85, 168pp.

Burt, D.M. \& London, D. 1982. Subsolidus equilibria. In: Granitic pegmatites in Science and Industry. Mac short course Handbook 8:329-346.

Cerny, P. 1991, Rare-clement granitic pegmatites. Part I: Anatomy and internal evolution of pegmatite deposits. Geosci. Can., 18/2:49-67.

Oniy, $P .1992$. Gcochcmical and pctrogcnclic features of mincralization in rare-clement pegmatites in the light of current research. Appl. Geochem., 7:393-416.

Chakoumakos, B.C, Lumpkin,G.R.,1990. Pressure-temperature constrains on the crystallization of the Harding pegmatite, Taos County, New Mexico. Can. Mineral., 28:287-298.

Charoy, B. \& Noronha, F. 1996. Multistage growth of a rare-clement volatile-rich microgranilc at Argcmcla (Portugal). J. Petrol., 37/1:73-94.

Charoy, B., Chaussidon, M., Noronha, F. (1995).Lithium y.onalion in white micas from the Argemcla microgranitc (central Portugal): an in-silu ion-cleciron-microprobc and spectroscopic investigation. Eur. J. Mineral., 7:335-352.

Charoy, B., Chaussidon, M., Duthou, J.L. Chemical and isotopic evidences from strontium mobility in the albilc-lcpidolitc-topax. granite of Bcauvoir (France): an in-situ ion and electron probe study of secondary Sr-rich phosphates, (submitted)

Charoy, B., Lhotc, F., Dusausoy, Y., Noronha, F. 1992. The crystal chemistry of spodumenc in some granitic aplitc-pcgmatilcs of Northern Portugal. Can. Mineral., 30:639-651.

Cheillelz, A., Archibald, D.A., Cuncy, M., Charoy, B. 1992 . Ages ${ }^{40} \mathrm{Ar}{ }^{39} \mathrm{Ar}$ du leucogranitc a topazc-ldpidolitc de Bcauvoir ct des pegmatites sodolithiques dc Chedevillc (Nord du Massif Central, France). Signification pgtrologique cl gcodynamiquc. C.R. Acad. Sci. Massif Central, France). Significa
Paris, t. 315, Sdric II, 329-336.

Cuncy, M., Marignac, C., Weisbrod, A., 1992. The Bcuvoir lopa/--lcpidolitc-albitc granite (Massif Central, France): the disseminated magmatic $\mathrm{Sn}$-Li-Ta-Nb-Bc mineralization. Econ. Geol. 87:1766-1794.

Dias, R. \& Ribciro, A. 1995. The Ibcro Armorican Arc: a collision effect against an irregular continent?. Tectonophy., 246:113-128.

D6ria, A., Charoy, B., Noronha, F. 1989. Fluid inclusion studies in spodumcnc aplitc-pcgmatitc dikes of Covas dc Barroso, Northern Portugal. ECROFIX, Imperial College, University of London, Abstracts, $\mathrm{p} 25$.

Duthou, J.L. 1977. Chronologic Rb-Sr ct gcochimic des granitóides d'un segment de la chainc varisquc, relations avcc Ic mdtamorphismc: Ic Nord Limousin, Massif Central franc,ais. Annales sclent. Univers. Clcrmont, 63, $294 \mathrm{p}$.

Ferreira, N., Iglcsias, M., Noronha, F., Percira, E., Ribciro, A., Ribciro, M.L. 1987. Granitoidcs da Zona Ccntro IBERICA c scu cnquadramento gcodinamica. In: Bca ct al. (cds.) Geologia de los Granitoides y Rocas asociadas del Macizo Hesperico. Editorial Rucda, Madrid (Libro Homcnajc a L.C. Garcia de Figucrola), pp 37-51.

Foster, H.D. 1960. Interpretation of the composition of lithium micas. Geol. Surv. Prof. Paper, (/SA354E, 115-146.

Fouillac, A.M. \& Rossi, P. 1991. Ncar-solidus ${ }^{18} \mathrm{O}$ depletion in a Ta-Nb-bcaring albilc granite: the Beauvoir granite, France. Econ. Geol., 86:1704-1720.

Jahns, R.H. 1953. The genesis of pegmatites. II. Quantitative analysis of lithium-bearing pegmatite, Mora County, New Mexico. Amer. Mineral., 38:1078-1112.

Jahns, R.H. \& Burnham, C.W. 1969. Experimental studies of pegmatite genesis: I. A model for the derivation and crystallization of granitic pegmatites. Econ. Geol., 64:843-864

Kovalenko, V.I., Kuz'min, M.I., Lctnikov, F.A. 1970. Magmatic origin of lithium and fluorine-bearing rare met al granites. Dokl. Akad. Nauk. SSSR, Earth Sci. Sect., 190:189-192.

Lagardc, J.L., Capdcvila, R., Fourcadc, S. 1992. Granites ct collision continental: rcxcmplc des granitoi'des carbonifcres dans la chainc hercynicnnc oucst-curopdcnnc. Bull. Soc. geol. France, 1.163 , n 5, 597-610.

Linnen, R.L., Pichavant, M., Holtz, F., Burgess, S. 1995. The effect of fOz on the solubility, diffusion, and spcciation of tin in haplogranitic melt at $850^{\circ} \mathrm{C}$ and $2 \mathrm{kbar}$. Geoch. Cosmoch. Acta, 59:1579-1588.

London, D. 1984. Experimental phase equilibria in the system LiAlSiO4-SiO2-H2O: a pctrogenctic grid for lithium-rich pegmatites. Amer. Mineral., 69:995-1004.

London, D. 1985. Origin and significance of inclusions in quartz: a cautionary example from the Tanco pegmatite, Manitoba. Econ. Geol., 80:1988-1995.

London, D. 1986. Magmalic-hydrothcrmal transition in the Tanco rare-clement pegmatite: evidence from fluid inclusions and phase-equilibrium experiments. Amer. Mineral., 71:376-395.

London, D. 1987. Internal differentiation of rare-clement pegmatites: effects of boron, phosphorus, and fluorine. Geoch. Cosmoch, Acta, 51, 403-420.

London, D. 1990. Internal differentiation of rare-clement pegmatites: a synthesis of recent research. Geol. Soc. of America. Spec. Paper, 246:35-50.

London, D. \& Burl, D.M. 1982. Chemical models for lithium aluminosilicalc stabilities in pegmatites and granites. Amer. Miner., 67:494-509.
London, D., Morgan, G.B., Hcrvig, R.L. 1989. Vapor-undcrsaturatcd experiments with Macusanitc glass $+\mathrm{H}_{2} \mathrm{O}$ at $200 \mathrm{MPa}$, and the internal differentiation of granitic pegmatites. Contr. Mineral. Petrol., 102:1-17.

Manning, D.A.C. 1981.The effect of fluorine on liquidus phase relationships in the system Qz-Ab-Or with excess water at $1 \mathrm{~kb}$. Contr. Mineral. Petrol., 76:206-215.

Matte, P. 1986. Tectonics and plate tectonics model for the Variscan belt of Europe. Tectonophy 126:329-374.

Matte, P. 1991. Accrctionary history and crustal evolution of the Variscan bell in Western Europe. Tectonophy., 196:309-337.

Matte, P. \& Ribciro, A. 1975. Forme ct orientation de Tellipsoîde de deTormation dans la virgation hercynicnnc dc Galicc. Relations avec Ic plissement ct hypothfescs sur la gen6sc de l'arc ibcro-armoricain. C.R.Acad. Sci. Paris, Sdr. D, 280:2825-2828.

Monicr, G. 1987. Cristallochimic des micas des leucogranilcs. Nouvcllcs donnces cxp $<5$ rimentalcs el applicalions pdlrologiques. Geol. Geoch. I'Uranium, .Mem. 14, 347 p. solid solutions with increasing lithium content: an experimental study in the system $\mathrm{K} 2 \mathrm{O}-\mathrm{Li} 2 \mathrm{O}-\mathrm{MgO}-\mathrm{FcO}-\mathrm{AhOj}-\mathrm{SiO} 2-\mathrm{H} 2 \mathrm{O}-\mathrm{H} \mathrm{F}$ at $600^{\circ} \mathrm{C}, 2 \mathrm{kbar} \mathrm{PH} 2 \mathrm{O}$ : comparison with natural lithium micas. Mineral. Mug., 50:641-651.

Monicr, G., Charoy, B., Cuncy, M., Ohncnstcllcr, D., Robert, J.L. 1987. Evolution spatialc cl tcmporcllc de la composition des micas du graniic albitiquc a topazc-16pidolilc dc Bcauvoir. Geol. France, 2-3:179-188.

Munoz, J.L. 1968. Physical properties of synthetic lepidolilc. Amer. Mineral., 53:1490-1512.

Munoz, J.L. 1971. Hydrothcrmal stability rclalions of synthetic lepidolitc. Amer. Mineral. 56:2069-2087.

Noronha, F., Ramos, J.M.F., Rcbclo, J., Ribciro, A., Ribciro, M.L. 1981.Essai dc correlation dcs phases de deformation hercynicnncs dans Ic NW dc la Pcninsulc Ibdriquc. Leid. Geol. Meded 52(1):89-91.

Ohncnsicllcr, D. \& Piantonc, P. 1992. Pyrochlorc-group minerals in the Bcauvoir pcraluminous Icucogranilc, MassifCentral, France. Can. Mineral., 30:771-784.

Pichavant, M., Boher, M., Stcngcr, J.F., Aissa, M., Charoy, B. 1987. Relations de phase des granites de Beauvoir a $1 \mathrm{ct} 3 \mathrm{kbar}$ en conditions dc saturation en H2O. Geol. France, 2-3:77-86.

Pichavant, M., Kontak, D.J., Briqucu, L., Valencia Hcrrcra, J., Clark, A.H. 1988. The Mioccnc-Ploccnc Macusani volcanics, SE Peru: 2: Geochemistry and origin of a felsic pcraluminous magma. Contr. Mineral. Petrol., 100:325-338.

Puyau, V. 1987. Petrographie etgeochimie des aplo-pegmatites hercyniennes de Vila Real (Nord Portugal) et de leurs micas. Unpub. DEA, Univ. P. 1 M. Curie, Paris VI.72p.

Raimbault, L. \& Burnol, L. The Richcmont rhyolilc dike (French Massif Central): a subvolcanic equivalent of rare-met al granites. Can. Mineral, (subm.)

Raimbaull, L. \& Azcncoll, C. 1987. Gdochimic des dldmenls majcurs cl traces du graniic a mdlaux rarcs de Bcauvoir. Geol. France, 2-3:189-198.

Raimbaull, L., Cuncy, M., Azcncoll, C., Dulhou, J.L., Joron, J.L. 1995. Gcochemical evidence for a multistage magmatic genesis of Ta-Sn-Li mineralization in ihe graniic al Bcauvoir, French Massif Central. Econ. Geol., 90:548-576.

Ramos, J.M.F. \& Noronha, F 1995. CondigOcs de dcposigao de fasc litinifcra principal no campo filoniano aplilopcgmatitico de Scixa Amarclo-Gon^alo. IV Congr. Nac. Geol. F. Sodré Borges \& M.M. Marques (Coords). Resumes alargados. Mem. Mus Labor. Miner. Geol. Fac. dene. Univ. Porto, 4:599-604.

Ramos, J.M.F., Barriga, J.A.S., Ribciro, A. 1995. O campo filoniano aplopegmatitico com mincralizac.ocs de mclais raros de Scixo Amarclo-Gonc,alo (Guarda) Algumas Notas sobrc a sua gencsc. IV Congrcsso Nacional de Geologia F. Sodrc" Borges \& M.M. Marques (Coords). Rcsumos alargados. Mem. Mus Labor. Miner. Geol, Fac. Cienc. Univ. Porlo, 4:593-598.

Ribciro, A., Antuncs, M.T., Ferreira, M.P., Rocha, R.B., Soarcs, A.F., Zbyszcwski, G., Moitinho dc Almcida, F., Carvalho, D., Montciro, J.H. 1979. Introduction a la Geologic du Portugal. Scrv. Geol. Portugal. Lisboa.

Ricdcr, M. 1970. Chemical composition and physical properties of lithium iron micas from Krusnd Hory Mis (Erzgcbirge). Part A: Chemical composition. Contr. Miner. Petrol., 27, 131-158.

Stcwarl, D.B. 1978. Pctrogcnesis of lithium-rich pcgmatiles. Amer. Mineral., 63:970-980.

Stussi, M. 1989. Granitoid chemistry and associated mincralisalion in the French Variscan. Econ. Geol., 84:1363-1381

Tischendorf, G. 1977. Gcochemical and petrographic characteristics of silicic magmatic rocks associated with rare-clement mineralization. In Stcmprok, M., Burnol, L. and Tischendorf, G, (cds.), MAWAM, Praha. Czechoslovakia Geol. Survey, 2:41-96.

Weber, K. 1984. Variscan cvenls: early Paleozoic conlincnlal rift metamorphism and late Paleozoic crustal shortening. In: D.H.W. Hullon \& D.J. Sandcrson (cds). Variscan Tectonics of the North Atlantic Region. Geol. Soc., Spec. Public. 14:3-22.

Webster, J.D., Thomas, R., Rhcdc, R., Foster, D., Stclmann, R. 1997. Melt inclusions in quartz from an evolved pcraluminous pcgmalitc: gcochcmical evidence from strong enrichment in fluorine-rich and phosphorus-rich residual liquids. Geoch. Cosmoch. Acta, 61/13:2589-2604

Whitworth, M.P. \& Rankin, A.H. 1989. Evolution of fluid phases associated with lilhium pcgmalilcs from SE Ireland. Mineral, Mag., 53:271-284.

Manuscrito A-1044

Recebido em 20 de novembro de 1997 Revisao dos autores em30 de junho de 1998 Revisao aceita em 15 de novembro de 1998
Monicr, G. \& Robert, J.L. 1986. Evolution of ihc miscibility gap bclwcen muscovilc and biolitc 